\title{
ポリ(ビニルアルコール)ゲルにおけるアミノ酸と アルコールの吸着と排斥
}

（1983 年 7 月 14 日 受 理）

\author{
平山忠一*・広野康孝・松本和秋**・本里義明
}

ポリ（酢酸ビニル）球状粒子を球形をたもったままケン化し，つづいてへキサメチレンニジイソシアナ ート，トリレンニジイソシアナート，エピクロロヒドリンおよび $\gamma$ 線照射で橋かけし 4 種のポリ（ビニル アルコール）球状ゲルを調製した。さらにポリ（トリフルオロ酢酸ビニル）をケン化し，その水溶液を エピクロロヒドリンで橋かけしてポリ（ビニルアルコール）ゲルを調製した。ポリ（ビニルアルコール） へのアミノ酸の吸着・排斥現象技よびアルコールのゲルとの間の疎水性相互作用を調べた。ゲル中に含 まれる酸性基は $\gamma$ 線照射， ジイソシアナートで橋かけされたゲルで $41 〜 46 \mu \mathrm{eq} / \mathrm{g}$ ，エピクロロヒドリン の場合で $18 \mu \mathrm{eq} / \mathrm{g}$ 以下で, これらき荷電のため酸性アミノ酸は排斥，塩基性アミノ酸は吸着された。 しかしポリ(トリフルオロ酢酸ビニル）から得られたゲルではアミノ酸の分配係数，重合時の重合率と 極限粘度の関係から酸性基はほとんど含まれないことが示唆される。エピクロロヒドリンまたは $\gamma$ 線照 射で橋かけされた PVA ゲルのアルコールとの間の蹯水性相互作用は他のゲルのそれょり小さい。

\section{1 緒言}

ゲルクロマトグラフィー水系充填郕では, ゲルマトリックスと 溶質の相互作用のため，溶質がゲルに吸着またはゲルから排斥さ れることがある。すでにデキストランゲルについては，ゲルマト リックス中に含まれるカルボキシル基によるアミノ酸の吸着, 排 斥効果が報告されている1。この副次効果は分子サイズの近い分 子を分離するためには有効であるが，分子サイズに基づく分離を 行ならゲルクロマトクラフィーにとっては障害となる。著者らは

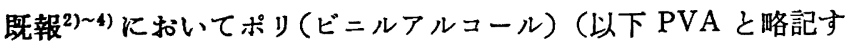
る）を素材とした水系充填剤の合成とゲルクロマトグラフィーに ついて報告してきた。そこでポり（酶酸ビニル（PVAc）とポリ (トリフルオロ酢酸ビニル) (PVTA) から PVAを合成し, これ を素材として既報34の方法で合成した各種 PVA 球状ゲル粒子の ゲルクロマトクララフィーに拈ける荷電による副次効果拉よび眯水 的副次効果を検討してゲルクロマトクラフィー水系充填郕として の有用性を調べた。

\section{2 実験}

\section{1 試 菜}

酰酸ビニルは常圧下 72.5 73. $0^{\circ} \mathrm{C}$ の留分を用いた。アゾビス イソブチロニトリルは市贩品をメタノールで再結晶して精製し

熊本大学工学部合成化学科, 860 熊本市黒辰

** 有明工業高等専門学校工業化学科, 836 大车田市東萩尾町

1) B. Gelotte, J. Chromatogr., 3, 330(1960).

2）本里妾明，平山忠一，日化，1972，1087.

3）平山忠一, 川口皓二, 本里義明, 日化, 1974, 894.

4) C. Hirayama, T. Honda, Y. Motozato, Polymer, 18, 1227 (1977).
た。エピクロロヒドリン $(\mathrm{ECH})$, メタノール，硫酸ナトリウム， 水酸化ナトリウム, アセトン, ジメチルスルホキシド, へキサン はいずれも試薬特級品をそのまま使用した。へキサメチレンニジ イソシアナート (HDI，日本ポリウレタン工業(株)製),トリレ ンシジインシアナート（以下 TDI と略記する，2,4-, 2,6-異性 体量比 $80: 20$, 和光純薬), 界面活性剂エマゾール $41 \mathrm{~S}$ (ソルビ タン脂肪酸エステル，日本油脂(株)製)およびその他の試薬（一 級)はそのまま使用した。

\section{2 ゲル球状粒子の調製}

酢酸ビニルに対して $1 \mathrm{wt} \%$ の過酸化ベンゾイルの存在下 $60^{\circ} \mathrm{C}$ で㲘渴重合して得た PVAC 球状粒子を既報引の方法でケン化して PVA 球状粒子を得た。PVA 球状粒子を HDI，TDI 拈よび ECH で橋かけしたもの（以下それぞれ A，B，C ゲルとする）を調製 した。またPVTAをケン化して得た PVA を $\mathrm{ECH}$ で橋かけし てEゲルを調製した。 A， B， C， D， Eゲルの調製法をつぎに 述べる。

2.2.1 A, B ゲルの調製：PVA 球状粒子 $30 \mathrm{~g}$ を橋かけ浴 （トルェン $300 \mathrm{~m} l$ 中に HDI をPVA に対して等モル溶解）に 加え $100^{\circ} \mathrm{C} ， 5$ 時間かきまぜた。反応後アセトンで Soxhlet 抽出 し水洗した。このゲルを A ゲルとする。また HDI のかわりに TDI を使用して同一方法で得たゲルを Bゲルとした。水踣潤状

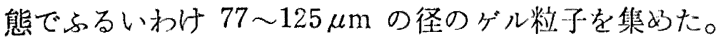

2.2.2 C ゲルの調製: PVA 球状粒子 $20 \mathrm{~g}$ を $2 \mathrm{~mol} / l$ 水酸化 ナトリウムのメタノール性水溶液（メタノール/水 $=1 / 1$ 容量比） $200 \mathrm{~m} l$ に室温で 4 時間浸漬後汇取し，橋かけ浴 $(0.5 \mathrm{~mol} \% \mathrm{ECH}$ のジメチルスルホキシドーアセトン（1:2 容量比）溶液） $500 \mathrm{ml}$ に加兄，かきぜながら $60^{\circ} \mathrm{C} て ゙ 6$ 時間反応した。水膨潤状態で

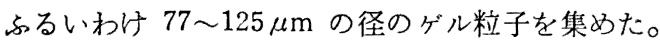


2.2.3Dゲルの調製：PVA 球状粒子を $5 \mathrm{wt} \%$ 硫酸ナトリウ

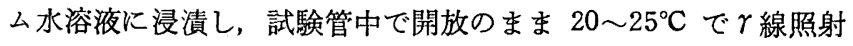
した。照射線量率は $6.8 \times 10^{5} \mathrm{R} / \mathrm{h}$, 全線量は $1.09 \times 10^{7} \mathrm{R}$ であ る。なお $\gamma$ 線照射線源は日本原子力研究所東海研究所 ${ }^{80} \mathrm{Co}-45 \mathrm{Kci}$ を用いた。得られた PVA 球状粒子を水膨閏状態でふるいわけし 77 125 $\mu \mathrm{m}$ の径のゲル粒子を集めた。

2.2.4 Eゲルの調製: 三フッ化酢酸ビニル5) はトリフルオロ 酢酸（試薬特級，常圧下 $70.0 \sim 70.5^{\circ} \mathrm{C}$ の留分を使用した）とア セチンン（市販ボンベ充填アセチレンを精製）を作用させ, 39.5 〜40.5 $5^{\circ} \mathrm{C} / \mathrm{atm}$ の留分を集めた。開始剤としてアゾビスイソブチ ロニトリル（モノマーに対して $1 \mathrm{wt} \%)$ を用いてトリフルオロ 酢酸ビニルを封管重合（窒素ガス雲囲気，40ㄷ，10〜 50 時間）し た。得られた PVTA はアセトン溶液からへキサンにより 2 回沈 殿精製を行なったのち，減圧乾燥した。PVTA のケン化反応は PVTA $3.7 \mathrm{~g}$ をアセトン $90 \mathrm{~m} l$ に溶解し, 室温でかきまぜなが ら $5 \mathrm{wt} \%$ 水酸化カリウムのメタノール溶液 $50 \mathrm{ml}$ を滴下した。 3 時間後, 減圧乾燥した。さらにケン化生成物全量を $20 \mathrm{wt} \%$ × タノール水溶液 $50 \mathrm{ml}$ に溶解し, $4 \mathrm{wt} \%$ 水酸化ナトリウム $50 \mathrm{ml}$ を加えて $90^{\circ} \mathrm{C}, 3$ 時間再ヶン化を行ない, メダノールで洗浄後 減圧乾燥した。合成した PVA $1.1 \mathrm{~g}$ を水酸化ナトリウム（橋か け剂 $\mathrm{ECH}$ に対して等モル) 水溶液に加温溶解して全量が $35 \mathrm{~g}$ になるよう水を添加して調製し， $60^{\circ} \mathrm{C}$ にたもった。

一方, $40 \mathrm{~m} l$ の灯油, $1 \mathrm{ml}$ のエマゾール $41 \mathrm{~S}, 10 \mathrm{~m} l$ の流動パ ラフィン, PVA に対して等モルの $\mathrm{ECH}$ からなる橋かけ浴を $60^{\circ} \mathrm{C}$ にたもち，かきまぜながら上記 PVA，溶液を加えて 24 時間 一定速度でかきまぜて応させる。得られたゲル球状粒子を洗浄

Table 1 Molecular characteristics of solute used for gel chromatography

\begin{tabular}{lrrc}
\multicolumn{1}{c}{ Sample $^{a)}$} & $\bar{M}_{\mathrm{w}}$ & \multicolumn{1}{c}{$\bar{M}_{\mathrm{n}}$} & Concn. (wt\%) \\
\hline PEO-SE-30 & 310000 & 280000 & 0.5 \\
PEO-SE-8 & 79000 & 73000 & 1.0 \\
PEG-20M & & 28500 & 2.0 \\
PEG-9000 & & 10350 & 2.0 \\
PEG-4000 & & 3300 & 2.0 \\
PEG-1000 & & 1160 & 2.0 \\
PEG-400 & & 450 & 2.0 \\
PEG-200 & & 240 & 2.0 \\
DEG & 106 & & 2.0 \\
EG & 62 & & 2.0 \\
Methanol & 32 & & 1.0 \\
1-Butanol & 74 & & 1.0 \\
1-Hexanol & 102 & & 0.5 \\
Cyclohexanol & 100 & & 1.0 \\
Glutamic acid & 106 & & 1.0 \\
Aspartic acid & 147 & & 1.0 \\
Glycine & 75 & & 1.0 \\
Alanine & 89 & & 1.0 \\
Phenylalanine & 165 & & 1.0 \\
Tryptophan & 204 & & 1.0 \\
Arginine & 174 & & 1.0 \\
Histidine & 155 & & 1.0 \\
a) PEO Poly & & &
\end{tabular}

a) PEO : Poly (ethylene oxide), PEG : Polyethylene glycol, DEG : Diethylene glycol, EG : Ethylene glycol.

5) B. W. Howk, R. A. Jacobson, U. S. P., 2, 436, 144(1948).

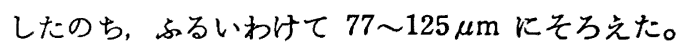

\section{3 ゲルクロマトクラフィー}

ゲルへの分子浸透性を調べるためにゲル粒子を内径 $0.5 \mathrm{~cm}$, 長さ $30 \mathrm{~cm}$ のジャケット付ガラスカラムに充埧し, 溶質として エチレングリコールの重合同族体（以下 PEG と略記する）を用 いた。またゲルの荷電による吸着, 排斥効果を調へるために酸性 アミノ酸, 中性アミノ酸, 塩基性アミノ酸を用いた。溶質は一括 して表1に示した。

溶出溶媒はイオン交換水を蒸留したものと $0.9 \mathrm{wt} \%$ 塩化ナト リウム水溶液とである。溶出液の流量は A， B , D ゲルで 0.6 $\mathrm{ml} / \mathrm{min}, \mathrm{C}$ ゲルで $0.4 \mathrm{ml} / \mathrm{min}, \mathrm{E}$ ゲルで $0.2 \mathrm{ml} / \mathrm{min}$, カラム 温度は $30^{\circ} \mathrm{C}$ 一定で行なった。溶質の検出は示差屈折計 (Model 6060，KNAUER, Germany）を使用した。カラム全容積を $V_{\mathrm{t}}$, 溶質の溶出容積を $V_{\mathrm{e}}$, ゲル粒子から完全に排除される大きさの 分子の溶出容積をゲル床間腺容積（以下 $V_{0}$ と略記する）とする と, 溶質のゲル粒子内外の分配係数（以下 $K_{\mathrm{av}}$ と略記する）は 次式竝わせる。

$$
K_{\mathrm{av}}=\frac{V_{\mathrm{e}}-V_{0}}{V_{\mathrm{t}}-V_{0}}
$$

\section{4 疎水性相互作用}

シクロヘキサノール，1-ヘキサノール，1-プタノール, メタノ 一ルの溶出容積をそれぞれ $V_{\mathrm{CychexOH}}, V_{\mathrm{HexOH}}, V_{\mathrm{BuOH}}, V_{\mathrm{MeOH}}$ としたときこれらと $V_{0}$ との差の比を求めて柾水性相互作用の 因子とした。

\section{5 電気電導度滴定法による酸性基の定量}

江口，松本らの方法7)に準じて行なった。ゲル粒子はイオン交 換水で十分に洗浄後, 絶乾し電気電導度滴定装置 (MY-7 型, (株)柳本製作所製)を用いた。

\section{6 膨潤度および保有水量8)}

ゲル粒子 3〜 $5 \mathrm{ml}$ を水とともに $10 \mathrm{ml}$ のメスシリンダーに入 れ， $60^{\circ} \mathrm{C}$ の恒温槽中に 6 時間静置し，脱気後膨潤 ゲル床の容積 $\left(V_{1} \mathrm{ml}\right)$ を测定した。つぎにメスシリンダー中のゲルをサランネ ットを張ったバスケット $\left(W_{1} \mathrm{~g}\right)$ に入れ，1000 rpm, 3 分間遠心 分離しゲル粒子間隙の水を除さ，バスケットごと精科 $\left(W_{2} \mathrm{~g}\right)$ し, さらに減圧乾燥し精科 $\left(W_{3} \mathrm{~g}\right)$ した。膨潤度は $V_{1} /\left(W_{3}-\right.$ $W_{1}$ ) (wet.gel-bed·m $l / \mathrm{dry} \cdot \mathrm{gel}-\mathrm{g}$ ), 保有水量は $\left(W_{2}-W_{3}\right) /$ $\left(W_{3}-W_{1}\right)\left(\mathrm{H}_{2} \mathrm{O}-\mathrm{g} / \mathrm{dry} \cdot \mathrm{gel}-\mathrm{g}\right)$ で表わした。

\section{3 結果亡考察}

\section{1 ゲルの性澌}

合成した 5 種のゲル粒子の性質を表 2 に示した。橋かけ剤の違 い, 素材の PVAの違いなどによってゲルの排除限界分子量, 膨 潤度，保有水量が異なった。またゲル中に含有される酸性基量は 橋かけ剂が HDI, TDI のA, B ゲルおよび けされた D ゲルはいずれも $41 〜 46(\mu \mathrm{eq} / \mathrm{g})$ を示した。橋かけ郕 のジイソシアナートが PVA と一官能基のみ結合する場合はゲル マトリックス中に酸性基生成の可能性がある。またPVAを 照射すると PVA 鎖の末端にカルボキシル基やカルボニル基が生

6) T.C. Laurent, J. Killander, J. Chromatogr., 14, 317 (1964).

7) 江口保, 松本昌一, 高分子化学, 15, 83(1958).

8）本里義明, 平山忠一, 松本和秋, 工化, 74, 1904(1971). 
Table 2 Properties of PVA gel beads

\begin{tabular}{ccccc} 
Gel No. & $\begin{array}{c}\text { Excluded critical } \\
\text { molecular weight }\end{array}$ & $\begin{array}{c}\text { Degree of swelling } \\
(\text { wet } \cdot \text { gel-bed } \cdot \mathrm{m} l / \mathrm{dry} \cdot \mathrm{gel}-\mathrm{g})\end{array}$ & $\begin{array}{c}\text { Water regain } \\
\left(\mathrm{H}_{\mathbf{2}} \mathrm{O}-\mathrm{g} / \mathrm{dry} \cdot \mathrm{gel}-\mathrm{g}\right)\end{array}$ & $\begin{array}{c}\text { Content of acid } \\
\text { groups }(\mu \mathrm{eq} / \mathrm{g})\end{array}$ \\
\hline A-gel & 1300 & 3.0 & 1.4 & 46 \\
B-gel & 3800 & 3.8 & 2.0 & 41 \\
C-gel & 6300 & 6.0 & 2.7 & below 18 \\
D-gel & 3000 & 4.0 & 2.1 & 43 \\
E-gel & 60000 & 25.0 & 10.0 & below 18
\end{tabular}

Table 3 Partition coefficient ${ }^{a}$ ) of amino acids using distilled water as an eluent

\begin{tabular}{|c|c|c|c|c|c|}
\hline \multirow{2}{*}{ Solute } & \multicolumn{5}{|c|}{ Gel No. } \\
\hline & $\widehat{A-g e l}$ & B-gel & C-gel & D-gel & E-gel \\
\hline Glutamic acid & 0.30 & 0.24 & 0.55 & 0.27 & 0.90 \\
\hline Aspartic acid & 0.30 & 0.25 & 0.54 & 0.35 & 0.92 \\
\hline Glycine & 0.60 & 0.69 & 0.71 & 0.69 & 0.92 \\
\hline Alanine & 0.60 & 0.64 & 0.73 & 0.67 & 0.89 \\
\hline Phenylalanine & 1.00 & 0.93 & 0.86 & 0.80 & 0.92 \\
\hline Tryptophan & 1. 90 & 1. 68 & 1. 30 & 1. 45 & 0.99 \\
\hline Arginine & Adsorption & Adsorption & Adsorption & Adsorption & 0.99 \\
\hline Histidine & Adsorption & Adsorption & Adsorption & Adsorption & 0.98 \\
\hline Diethylene glycol & 0.65 & 0.69 & 0.77 & 0.73 & 0.86 \\
\hline
\end{tabular}

a) $K_{\mathrm{av}}$ : Calculated from elution diagrams according to the equation (1).

Table 4 Partition coefficient ${ }^{a}$ ) of amino acids using $0.9 \mathrm{wt} \%$ sodium chloride aqueous solution as an eluent

Gel No.

\begin{tabular}{lccccc}
\multicolumn{1}{c}{ Solute } & A-gel & B-gel & C-gel & D-gel & E-gel \\
\hline Glutamic acid & 0.45 & 0.56 & 0.63 & 0.47 & 0.86 \\
Aspartic acid & 0.45 & 0.53 & 0.62 & 0.45 & 0.91 \\
Glycine & 0.72 & 0.60 & 0.71 & 0.57 & 0.88 \\
Alanine & 0.72 & 0.87 & 0.90 & 0.79 & 0.88 \\
Phenylalanine & 0.95 & 0.63 & 0.71 & 0.58 & 0.88 \\
Tryptophan & 1.85 & 1.56 & 1.36 & 1.32 & 1.00 \\
Arginine & 0.80 & 0.80 & 0.84 & 0.79 & 0.90 \\
Histidine & 0.75 & 0.69 & 0.69 & 0.69 & $0 . \varepsilon 3$ \\
Diethylene glycol & 0.75 & 0.69 & 0.76 & 0.66 & $0 . \varepsilon 6$
\end{tabular}

a) $K_{\mathrm{av}}$ : Calculated from elution diagrams according to the equation (1).

成することが桜田らによって報告されている

一方，PVAc および PVTA から得られた PVAをそれぞれ $\mathrm{ECH}$ で橋かけした C，Eゲルでは酸性基は $18(\mu \mathrm{eq} / \mathrm{g})$ 以下で あった。なおこれ以下の值は技術上難しかった。これらのことか ら橋かけ剤の種類，橋かけ方法によって酸性基量が異なり，橋か け剂がジイシアナートの場合と $、$ 線照射による橋かけの場合は 酸性基が多く，ECH の場合は酸性基が少ないことがわかった。

\section{2 ゲルマトリックス中の酸性基含量とアミノ酸の溶出特性}

5 種の PVA ゲルについて, イオン交换水を溶出溶媒に用いた ときの各種アミノ酸とそれに同程度の分子サイズのジェチレング リコールの $K_{\mathrm{av}}$ 值を表 3 に示した。3.1で述べたよらに 5 種のゲ ルの排除限界分子量が異なるので溶出位置の比較は $K_{\mathrm{av}}$ 值で判 断し,アミノ酸類と近似の分子サイズのジェチレングリコールの $K_{\mathrm{av}}$ 值と比較して考察する。酸性アミノ酸の $K_{\mathrm{av}}$ 值は $\mathrm{A}, \mathrm{B}$, $\mathrm{D}$ ゲルのいずれにおいてもジェチレングリコールの $K_{\mathrm{av}}$ 值と比

9）㮃田一郎，松沢秀二，高分子化学，17，268(1960).
較して非常に小さく， $\mathrm{E}$ ゲルではジェチレングリコールの $K_{\mathrm{av}}$ 値とほとんど同じ值を，Cゲルではその中間の値を示している。 また中性アミノ酸の $K_{\mathrm{a} \mathrm{v}}$ 值はいずれのゲルにおいてもジェチレ ングリコールの $K_{\mathrm{av}}$ 値とほとんど同じ值を示す。

一方, 塩基性アミノ酸は A， B， C，D ゲルではいずれも吸着

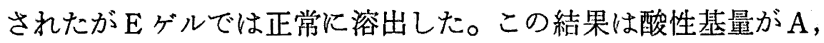
B， D ゲルで多く， C， E ゲルで少ない事揍と対応するが， Cゲ ルと E ゲルではE ゲルの方が酸性アミノ酸の排斥と塩基性アミ， 酸の吸着がほとんど見られないことから，Eゲルの酸性基はCゲ ルのそれより少ないと推察される。

フェニルアラニンは A， B ゲルでわずかに遅れて溶出し， C， D， E ゲルでほぼ正常に溶出した。また分子内に複素環を有する トリプトファンは A， B ゲルでジェチレングリコールに比較して かなり遅れる。これは A， B ゲルでは橋かけに用いられたジイソ シアナート中のアルキル鎖やフェニル基がゲルマトリックス中に 導入され，これと溶質の疎水性相互作用による溶出の遅れと考点 られる。 
Table 5 Factors of interaction between gel matrix and solute

\begin{tabular}{cccc} 
Gel No. & $\left(V_{\mathrm{BuOH}}-V_{0}\right) /\left(V_{\mathrm{MeOH}}-V_{0}\right)$ & $\left(V_{\mathrm{HexOH}}-V_{0}\right) /\left(V_{\mathrm{MeOH}}-V_{0}\right)$ & $\left(V_{\mathrm{HexOH}}-V_{0}\right) /\left(V_{\mathrm{CychexOH}}-V_{0}\right)$ \\
\hline A-gel & 1.38 & 2.71 & 1.58 \\
C-gel & 1.14 & 1.50 & 1.07 \\
D-gel & 1.18 & 1.50 & 1.04
\end{tabular}

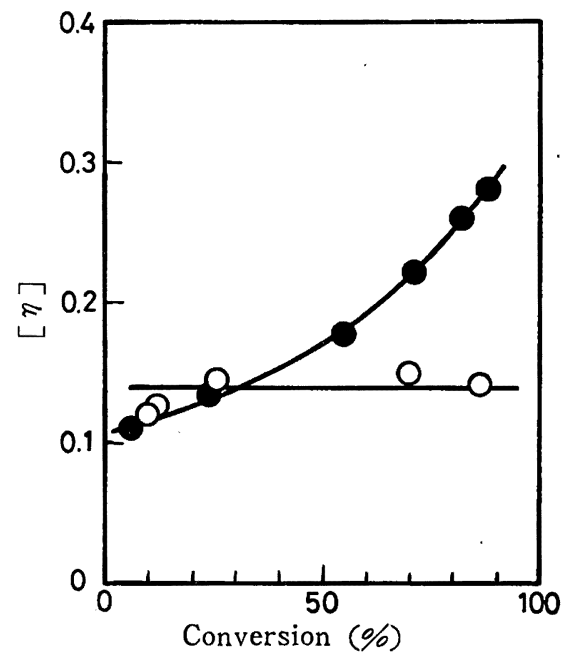

Fig. 1 Relationship between intrinsic viscosity and conversion

$\bigcirc$ : Poly (vinyl trifluoroacetate) from bulk polymerization

: Poly (vinyl acetate) from suspension polymerization

溶出溶媒として $0.9 \mathrm{wt} \%$ 塩化ナトリウム水溶液を用いて同じ 実醉を行なった結果を表 4 に示した。酸性アミノ酸, 塩基性アミ ノ酸がジェチレングリコールとほぼ同位置で溶出することから, 溶出溶媒としてイオン交換水を用いたときの A， B， C, D ゲル に見られた酸性アミノ酸の排斥現象と塩基性アミノ酸の吸着現象 はゲルマトリックスの酸性基 $\ominus$ 荷電と溶質の荷電による相互作用 が原因であることがわかる。以上の結果, PVA の橋かけは $\mathrm{ECH}$ を橋かけ剤として使用することによってゲル中の酸性基を少なく できることが判明した。

\subsection{PVTA からの PVA ゲル}

PVA を $\mathrm{ECH}$ で橋かけした C, Eゲルにおいて, 上述のよう にアミノ酸の排斥, 吸着現象の相違から $\mathrm{E}$ ゲルの方が Cゲルより も酸性基が少ないことが推察できるが,この原因は原料の PVAc, PVTA にあると考学られる。酢酸ビニルのラジカル重合では, 生成 PVAc のアセチル基からの二次的ラジカル重合によって, 重合率の増加とともに重合体の重合度または極限粘度 $[\eta]$ が急 激に上昇し，そのケン化生成物の PVA 鎖末端にカルボキシル基 が生成する(10)ことが知られている。因 1 亿著者らが行なった酢酸 ビニルおよびトリフルオロ酢酸ビニルの $60^{\circ} \mathrm{C}$ におけるラジカル 重合の重合率と生成重合体の [ $\eta]$ 関係を図示した。

酢酸ビニルの䀣濁重合では重合率の増加とともに $[\eta]$ が増加 するが, トリフルオロ酢酸ビニル塊状重合では重合率の增加によ っても [ク]はほぼ一定值をとった。このことはトリフルオロ酢

10）井上良三，桜田一郎，高分子化学， 7, 211(1950).
酸ビニルのラジカル重合では側鎖エステルからの二次的ラジカル 重合は打きにくいことを示し，PVTAは枝わかれが少なく，ケン 化生成物の PVA はカルボキシル基が少ないことが示唆される。

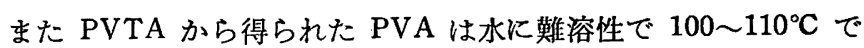
溶解すること, 916 と $849 \mathrm{~cm}^{-1}$ の吸光度比 ${ }^{11)} D_{916} / D_{849}$ が 0.51 を示すことからシンジオタクトに富み，PVAc からの PVA は $70^{\circ} \mathrm{C}$ 前後の水に溶解し $D_{916} / D_{849}$ は 0.26 前後であることから アタクチックと考えられる。これらのことから PVTA から得ら れた PVA は PVAc から得られた PVA よりも立体規則珄が高 くカルボキシル基が少ないと考えられる。したがって Cゲルと $\mathrm{E}$ ゲルに拈ける酸性アミノ酸の排斥, 塩基性アミノ酸吸着現象の相 違はゲル素材の PVA 中に含まれるカルボキシル基量の違いによ ると考えられる。

\section{4 ゲルマトリックスと溶質の疎水性相互作用}

表 5 に橋かけ剤の異なる PVA ゲルにおけるゲルマトリックス とアルコールの柾水性相互作用の因子を示した。アルキル鎖長の 異なるメタノール，1ーブタノール，1一ヘキサノールを溶出した結 果, $\left(V_{\mathrm{BuOH}}-V_{0}\right) /\left(V_{\mathrm{MeOH}}-V_{0}\right),\left(V_{\mathrm{HexOH}}-V_{0}\right) /\left(V_{\mathrm{MeOH}}-V_{0}\right)$ は ケ線照射による橋かけゲル（Dゲル）と ECHによる橋かけゲ ル (Cゲル) で小さく, HDIによる橋かけゲル (Aゲル) で大 きい。分子サイズによる分離では上記因子は1 以下でなければな らないが，いずれも 1 以上の值であることから，アルコールのア ルキル鎖部分とゲルマトリックス中の疎水部の相互作用が示唆さ れる。HDI を使用した場合には PVA 鎖間は-O- $\left(\mathrm{CH}_{2}\right)_{6}-\mathrm{O}-$ 鎖 によって橋かけされ，それと溶質のアルキル鎖との疎水性相互作 用によって溶出に大きな遅れが生じると考えられる。

一方，橋かけ剂が ECH では PVA 鎖間は - $-\mathrm{CH}_{2}-\mathrm{CH}(\mathrm{OH})-$ $\mathrm{CH}_{2}-\mathrm{O}-$ にって橋かけされ， $\gamma$ 線照射では生成したラジカル同 士の再結合によって橋かけされるため，いずれの橋かけ方法でる 疎水性の増加は少ないと考えられる。C，D ゲルの $\left(V_{\mathrm{BuOH}}-\right.$ $\left.V_{0}\right) /\left(V_{\mathrm{MeOH}}-V_{0}\right)$ が $1.14 \sim 1.18$ の值は, 既報の 2-ヒドロキシ エチル=フクリラートゲル12)の $1.2 \sim 1.5,2$-ヒドロキシェチル= メタクリラートゲル12)の $1.5 \sim 2.0$, ポリエチレングリュール=メ タクリラートゲル13)の $1.3 \sim 1.7$ と比较して非常に小さい。

$\left(V_{\mathrm{HexOH}}-V_{0}\right) /\left(V_{\mathrm{CychexOH}}-V_{0}\right)$ は $\mathrm{A}, \mathrm{C}, \mathrm{D}$ ゲルいずれに おいても 1 より大きいことから 1-へキサノールの方がシクロへ キサノールよりゲルマトリックスとの疎水性相互作用が大きく. とくにAゲルとの間では大きい。

以上の結果, PVA の橋かけ剤が HDI の場合はゲルマトリッ クスと溶質の蹯水的相互作用が大きく，橋かけ剂が $\mathrm{ECH}$ の場合 と $\gamma$ 線照射による橋かけの場合は上記蹯水性相互作用が小さいこ とがわかった。

11）村橋俊介, 野桜俊一, 高分子化学, 23，550(1969).

12）松本和秋, 平山忠一, 本里義明, 日化, 1983, 1040.

13）平山忠一, 松本和秋, 本里義明, 日化, 1983, 1143. 


\section{4 結 論}

各種調製法で得た PVA ゲルにアミノ酸, アルコールを溶出し てゲルクロマトグラフィーに拈ける副次効果を調べた結果つぎの ことが結論される。

1）橋かけ剂の種類と橋かけ方法によって PVA ゲル中に含有 される酸性基量は異なり，その量は $\gamma$ 線照射による橋かけゲルと ジインシアナートによる橋かけゲルで 41４6( $4 \mathrm{eq} / \mathrm{g})$, エピク ロロヒドリンによる橋かけゲルで $18(\mu \mathrm{eq} / \mathrm{g})$ 以下であった。こ の酸性基によるも荷電のために塩基性アミノ酸が吸着され，酸性
アミノ酸は中性アミノ酸より早く溶出する。

2）ポリ(トリフルオロ酢酸ビニル) から得られた PVA, ポリ (酢酸ビニル) から得られた PVAをそれぞれェピクロロヒドリ ンで橋かけしたゲルでは, 前者の方が後者より酸性基が少ないこ とが，（a）アミノ酸の溶出結果，（b）トリフルオ口酢酸ビニル と酢酸ビニルの重合率極限粘度の関係とから示唆される。

3） PVA ゲルマトリックスと溶質の疎水性相互作用は, エピ クロロヒドリンまたは 線照射で橋かけされたゲルでは非常に小 さい。

\title{
Adsorption and Exclusion of Amino Acids and Alcohols on Poly(vinyl alcohol) Gel Beads
}

\author{
Chuichi Hirayama*, Yasutaka Hirono, Kazuaki Matsumoto** \\ and Yoshiaki Motozato \\ Department of Synthetic Chemistry, Faculty of Engineering, Kumamoto \\ University; Kurokami, Kumamoto-shi 860 Japan \\ ** Department of Industrial Chemistry, Ariake Technical College ; \\ Higashihagio, Omuta-shi 836 Japan
}

Several kinds of poly(vinyl alcohol) (PVA) gel beads were prepared from PVA beads by saponification of poly(vinyl acetate) beads, followed by crosslinking with hexamethylene diisocyanate, tolylene diisocyanate, epichlorohydrin $(\mathrm{ECH})$ and by $\gamma$-ray irradiation, or from aqueous solution of PVA by saponification of poly(vinyl trifluoroacetate), followed by crosslinking with ECH. Adsorption and exclusion of amino acids on PVA gels were examined and the degrees of hydrophobic interactions between gel matrix and sample were measured by eluting alcohols. Adsorption and exclusion of amino acids were hardly observed on PVA gels derived from poly (vinyl trifluoroacetate), but clearly observed on the other PVA gels. The values of partition coefficient of amino acids and the relationship between conversion and intrinsic viscosity suggest that PVA gels derived from poly(vinyl trifluoroacetate) do not contain acid group. Hydrophobic interactions between gel matrix and alcohol on PVA gels crosslinked with epichlorohydrin or $\gamma$-ray irradiation were less than that of other gels. 